\title{
Liver function tests and urinary albumin in house painters with previous heavy exposure to organic solvents
}

\author{
Ingvar Lundberg, Gun Nise, Gunilla Hedenborg, Margareta Högberg, Olof Vesterberg
}

\begin{abstract}
The serum activities or concentrations of aspartate aminotransferase (ASAT), alanine aminotransferase (ALAT), alkaline phosphatase (ALP), albumin, $\gamma$-glutamyl transpeptidase (GGT), bilirubin (BIL), cholic acid (CHOL), chenodeoxycholic acid (CHENO), and transferrin with isoelectric point $5 \cdot 7$, and the urinary excretion of albumin were determined among male current or former house painters (n $=135)$ and house carpenters $(n=71)$ who had worked in their trades for at least 10 years before 1970. Workers who showed a value above the 90th percentile among the carpenters in at least one of the tests ASAT, ALAT, GGT, BIL, CHOL, or CHENO were regarded as showing "possible signs of liver dysfunction". Each participant's lifetime solvent exposure was evaluated by interview. The painters were divided into categories with low, intermediate, and heavy cumulative exposure during life (LTSE) or during the most exposed year (MEYSE). All participants stated none or slight recent exposure. The prevalence of possible signs of liver dysfunction increased with solvent exposure category according to LTSE as well as MEYSE with a numerically higher risk estimate in the heavy exposure category for MEYSE than for LTSE. ALP activity increased with exposure category according to both exposure estimates. This increase seemed to be due to an interaction between exposure to solvents and current or previous long term intake of medicines potentially toxic to the liver. None of these results was affected by whether or not the subjects had been exposed to solvents during the year before the investigation. The exposure to solvents was not significantly related to any other outcome variable. It is concluded that long term heavy exposure to solvents may elicit changes in conventional liver function tests indicative of a mild chronic effect on the liver. The findings also suggest that heavy solvent exposure during shorter time periods is a more likely cause of the findings than lifetime cumulative solvent exposure and that an interaction between solvent exposure and medicines potentially harmful to the liver may be important in the causation of the effects.
\end{abstract}

(Occup Environ Med 1994;51:347-353)
Some halogenated solvents-for example, 1,1,2,2-tetrachloroethane, carbon tetrachloride, and chloroform-are classical heptotoxins. The liver toxicity of these solvents is due to metabolic activation with formation of reactive metabolites. Because hepatotoxicity is a striking feature of these solvents it has been suspected that other solvents commonly used today may also be hepatotoxic. ${ }^{1}$

Most epidemiological studies to determine the hepatotoxicity of industrial solvents in widespread use - such as white spirit, toluene, and xylene-have shown no effect of ongoing exposure on routine liver enzymes in serum, ${ }^{2-4}$ but recent studies have found an increase in bile acids in serum among workers exposed to mixed solvents as well as among workers exposed to styrene. ${ }^{5-8}$

Some studies have suggested that exposure to organic solvents may induce glomerulonephritis, ${ }^{910}$ whereas other studies did not find an increased risk. ${ }^{11} 12$ Increased albumin excretion, as a marker of glomerular damage, has been found in groups of workers with ongoing solvent exposure in some studies ${ }^{13-16}$ and other studies have found increased excretion of enzymes or of retinol binding protein, indicating tubular dysfunction, but not of albumin. ${ }^{17-19}$

The long term significance of the findings concerning markers of liver and kidney dysfunction in groups of active workers has, however, to our knowledge never been investigated. This study examines liver function and albumin excretion in a group of current or former house painters who had been active in their trades for at least 10 years before 1970. They had all been exposed to high solvent concentrations for extended periods, but their current exposure was low or none. The decrease in solvent exposure was due primarily to an extensive shift from solvent based to water based paints during the past decades. Thus the study also provided a possibility to examine potential effects of exposure to water based paints.

\section{Materials and methods}

STUDY GROUP

The original population considered for the study were the members of the painters union and the carpenters in the union of building workers in Stockholm who were born in 1925 or later, who were members of the Stockholm branches of their respective trade unions in 1965 , and who had been members for at least 10 years before 1970 . These eligibility criteria 
were chosen to locate painters who had been working during the 1950 s and 1960 s when exposure to organic solvents was high among painters in Stockholm. ${ }^{20}$

Information on the eligibility criteria was collected from the membership registries of the respective trade union. The inclusion criteria were met by 767 painters and 1212 carpenters.

A sample of 149 painters and 85 carpenters were invited, in a random order, to a clinical examination in 1988-9 as part of a larger ongoing study focusing on the relation between organic solvent exposure and neuropsychiatric effects ${ }^{21} ; 135$ painters and 71 carpenters came to the examination.

\section{EXPOSURE}

Interview

All participating workers were interviewed by an occupational hygienist (GN) regarding their entire exposure history. The exposure to solvents during work and leisure time since first exposure was obtained in detail. In the interview the different jobs held by the subject were listed and the duration of the jobs was estimated. The average work time per day in different jobs was noted. For the painters the average amount of time actually spent painting, as compared with other tasks, was totalled. The time spent painting indoors $v$ outdoors, the amount of time working with roller or brush $v$ spraying, and the fraction of time wearing a respirator was estimated as a percentage of total work time for every job held.

Outdoor exposure to all types of paints was estimated to have provided only a small fraction of the cumulative exposure of each participant and was excluded from all exposure calculations. Taking roller or brush painting as unity it was assumed that spray painting doubled and adequate use of respirators halved the exposure. These relations were derived from the papers by Riala et $a l^{22}$ and Fidler $e t a{ }^{23}$ and from personal experience.

Painting or other exposure during leisure time was included in the exposure calculations in the same way as occupational exposure.

Finally the time actually spent painting, with appropriate corrections, was totalled in "painting-months"; one painting-month being equivalent to 176 work hours.

The participants were exposed to several solvents although exposure to white spirit always constituted a large share of the total exposure for all painters. On certain occasions such as painting ships, tanks, industrial buildings with special requirements, or painting in hospitals and gluing laminated boards in elevators or kitchens toluene or xylene had constituted the major part of the solvent exposure. Such work was totalled in paintingmonths in the same way as work in which white spirit was the major exposure, and included in the exposure calculations.

Working with water based paints was judged to involve a very low solvent exposure, which was not included in the calculations.
The direct solvent exposure of the carpenters was almost exclusively due to the use of solvent based glues. This use was calculated as equivalent to painting with a roller or brush indoors. The solvents most often used by the carpenters were xylene, toluene, butanols, and white spirit.

\section{Exposure estimates}

Lifetime cumulative solvent exposure (LTSE)The exposure to solvent in air during a painting-month is likely to have been different during different time periods. Compilations of measurements from previous decades showed that the average eight hour time weighted average exposure to white spirit during a painting-month was close to the hygienic standard during that period (Nise et al, unpublished observations). A reduction of the solvent content in the paints generally coincided with a lowered hygienic standard. Thus the fraction of the 1988 Swedish white spirit hygienic standard enforced during a particular time period (white spirit standard factor) was multiplied by the number of painting-months during that period to get a number of hygienic standard-months (HSMs). Table 1 shows the hygienic standards for Swedish white spirit during different periods and the white spirit standard factor applied during each period. Finally the HSM accumulated during different periods was totalled. For each subject the general form of our cumulative solvent exposure index is given by:

$$
\mathbf{H S M}=\sum_{\mathrm{i}} \sum_{\mathbf{x}} \sum_{\mathbf{i}} \sum_{\mathbf{m}}\left(\mathbf{T}_{\mathrm{i}} \times \mathbf{F}_{\mathrm{jklm}}\right)
$$

where $\mathrm{i}=$ the ith job; $\mathrm{T}=$ painting months; $F=$ the fraction of time; $j=$ form of application ( $1=$ roller or brush, $2=$ spray); $k=$ work with solvent based paints $(=1)$, with water based paints $(=0) ; 1=$ respirator (protecting factor $=0.5) ; \quad m=$ white spirit standard factor.

Most exposed year solvent exposure (MEYSE) This consisted of HSMs accumulated during the year with the most intense solvent exposure during the career as a painter.

Last year solvent exposure (LYSE)-This consisted of HSMs accumulated during the year before the investigation. Sixty six of the painters had no current solvent exposure as they worked only with water based paints, had changed to a non-exposed occupation, or had retired early.

Lifetime water-based paint exposure (LTWBE) - This exposure was estimated in accordance

Table 1 The Swedish hygienic standards for white spirit daring different periods and the corresponding white spirit standand factors

\begin{tabular}{lll}
\hline Time period & $\begin{array}{l}\text { White spirit } \\
\text { hygienic standard } \\
\text { (ppm) }\end{array}$ & $\begin{array}{l}\text { White spirit } \\
\text { standard factor }\end{array}$ \\
\hline-1973 & 200 & 2.4 \\
$1974-8$ & 100 & 1.2 \\
$1979-$ & 85 & 1.0 \\
\hline
\end{tabular}


Table 2 Distribution of different exposure estimates in exposure categories among the painters. The carpenters' LTSE ranged from 0 to 46 hygienic standard months (HSMs) ( $n=$ number of painters in each category)

\begin{tabular}{|c|c|c|c|c|c|c|}
\hline \multirow[b]{2}{*}{$\begin{array}{l}\text { Exposure estimate } \\
\text { (units) }\end{array}$} & \multicolumn{6}{|c|}{ Exposure category } \\
\hline & $n$ & $\begin{array}{l}\text { Category } 1 \\
\text { (lowest) }\end{array}$ & $n$ & $\begin{array}{l}\text { Category } 2 \\
\text { (intermediate) }\end{array}$ & $n$ & $\begin{array}{l}\text { Category } 3 \\
\text { (highest) }\end{array}$ \\
\hline $\begin{array}{l}\text { LTSE } \\
\text { (HSMs) }\end{array}$ & 34 & $55-131$ & 67 & $135-245$ & 34 & $246-438$ \\
\hline $\begin{array}{l}\text { MEYSE } \\
\text { (HSMs) }\end{array}$ & 35 & $6 \cdot 9-9 \cdot 8$ & 70 & $10 \cdot 2-17 \cdot 8$ & 30 & $18 \cdot 6-40$ \\
\hline $\begin{array}{l}\text { LYSE } \\
\text { (HSMs) }\end{array}$ & 66 & $<0 \cdot 1$ & & & 69 & $0 \cdot 1-4 \cdot 5$ \\
\hline $\begin{array}{l}\text { LTWBE } \\
\text { (water-based-months) }\end{array}$ & 40 & $9-42$ & 50 & $43-69$ & 45 & $72-122$ \\
\hline $\begin{array}{l}\text { LYWBE } \\
\text { (water-based-months) }\end{array}$ & 44 & 0 & 49 & $0 \cdot 1-2 \cdot 9$ & 42 & $3 \cdot 0-11 \cdot 1$ \\
\hline
\end{tabular}

with that of the solvent based paints but was not weighted according to any hygienic standard. It was totalled in water-based-months.

Last year water based paint exposure ( $L Y W B E$ ) - This was the number of waterbased-months during the year before the investigation.

Table 2 shows the variations in the different exposure estimates. In the statistical analyses the exposure estimates were categorised as in this table. Most of the painters had their heaviest solvent exposure during the 1960s and the use of solvent based paints decreased considerably after that. During the five years before the investigation only $0-14 \%$ (median $2 \%$ ) of the total HSMs were accumulated among the individual painters (figure)

\section{INFORMATION ON POTENTIAL CONFOUNDING} FACTORS

The participants were interviewed for potential confounding factors. The confounding factors considered were:

(a) Age.

(b) Alcohol consumption. The participants were asked about their average consumption of spirits, wine, and beer each week during the past year. The consumption of the different beverages was totalled as $\mathrm{g} 100 \%$ alcohol from data on their average alcohol contents.

(c) The degree of obesity. This may affect several tests of liver function. The weight and the length of the subjects were measured and Broca's index $(100 \times$ (weight in $\mathrm{kg}) /($ height in $\mathrm{cm} \mathrm{-} \mathrm{100))} \mathrm{was} \mathrm{calculated.}$

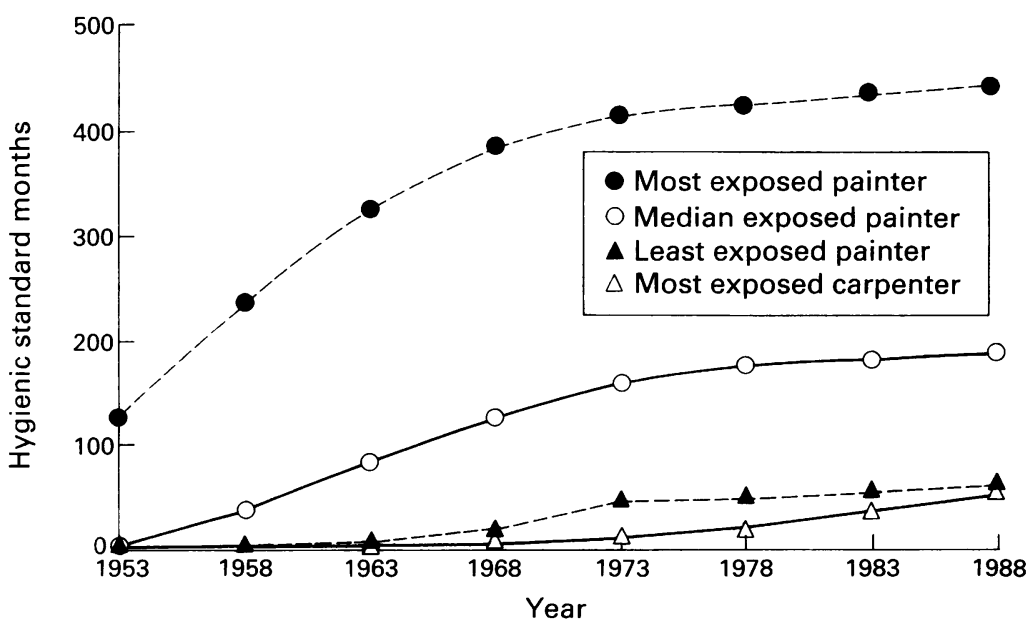

Cumulative solvent exposure accumulated by calendar years. (d) Present or previous long term intake of medicines potentially harmful to the liver (used in analyses of liver function tests) or the kidney (used in analyses of urinary albumin) according to the Swedish reference book of drug information (FASS), which contains all drugs approved by the Medical Products Agency in Sweden. The drugs were mostly antihypertensive agents, analgesics, sleeping pills and tranquilisers, and anti-inflammatory drugs.

(e) Blood pressure. This may affect albumin excretion in urine. Blood pressure was measured after five minutes of rest with a conventional cuff. The systolic pressure showed a stronger relation to urinary albumin excretion than the diastolic pressure and was used in the analyses.

$(f)$ Past or present liver or kidney disease. The large majority of previous kidney diseases were kidney stones and previous liver diseases included hepatitis and those of the gall bladder. Few subjects stated such diseases and they were not shown to affect any outcome. Thus these variables were not used as potential confounders in the data analysis.

For the analyses the potential confounders were categorised. Age, Broca's index, and systolic blood pressure were dichotomised by the medians, 50 years, and 104, and $140 \mathrm{~mm} \mathrm{Hg}$ respectively. Alcohol consumption was dichotomised at a weekly consumption of $126 \mathrm{~g}$ alcohol.

Table 3 gives the distribution of the potential confounders according to LTSE.

\section{OUTCOMES}

The participants were examined on a Monday, Tuesday, Wednesday, or Thursday. They had been instructed not to eat or drink for eight hours before the investigation. When coming to the investigation at around $8.00 \mathrm{am}$ blood samples were obtained from the cubital vein and the participants were asked to urinate and the time of urination was noted.

After some initial tests of neuropsychiatric function and the exposure interview the subjects were told to urinate again at around $11.00 \mathrm{am}$ and the time of the urination was noted. The volume of this urine sample was measured. Then the urine samples were frozen and stored at $-70^{\circ} \mathrm{C}$ until the analysis of urinary albumin, as an index of glomerular kidney function, and urinary creatinine. The creatinine analyses were performed at the hos- 
Table 3 Number of subjects with potential confounding factors according to LTSE exposure estimate

\begin{tabular}{|c|c|c|c|c|}
\hline Potential confounder & $\begin{array}{l}\text { Carpenters } \\
(n=71)\end{array}$ & $\begin{array}{l}\text { Painters } \\
(\text { low }) \\
(n=34)\end{array}$ & $\begin{array}{l}\text { Painters } \\
\text { (intermediate) } \\
(n=67)\end{array}$ & $\begin{array}{l}\text { Painters } \\
(\text { high }) \\
(n=34)\end{array}$ \\
\hline $\begin{array}{l}\text { Age } \geqslant 50 \text { years } \\
\text { Average alcohol consumption per week during past year }\end{array}$ & 31 & 7 & 40 & 25 \\
\hline$\geqslant 126 \mathrm{~g}$ & 16 & 10 & 21 & 4 \\
\hline Broca's index (see text) $\geqslant 104$ & 42 & 15 & 31 & 15 \\
\hline Systolic blood pressure $\geqslant 140 \mathrm{~mm} \mathrm{Hg}$ & 43 & 17 & 46 & 24 \\
\hline Past or present liver disease & 5 & 0 & 6 & 2 \\
\hline Use of medicines potentially harmful to the liver & 11 & 5 & 11 & 10 \\
\hline Past or present kidney disease & 7 & 6 & 11 & 4 \\
\hline Use of medicines potentially harmful to the kidney & 4 & 1 & 2 & 2 \\
\hline
\end{tabular}

pital laboratory according to Kodak Ektachem $\mathrm{T}-700$ test methodology and the albumin analyses at the Division of Medical Chemistry, Swedish National Institute of Occupational Health by the method of Vesterberg. ${ }^{24}$ The urinary albumin concentration was corrected for urinary creatinine.

The blood was centrifuged and most of the serum was immediately transferred to the hospital laboratory.

Aspartate aminotransferase (ASAT), alanine aminotransferase (ALAT), alkaline phosphatase (ALP), $\gamma$-glutamyl transpeptidase (GGT), albumin, and bilirubin (BIL) were determined the same day (Kodak Ektachem T-700 test methodology).

Serum for the determination of cholic acid (CHOL) and chenodeoxycholic acid (CHENO) was frozen at $-20^{\circ} \mathrm{C}$ and analysed within two months by radioimmunoassay with antisera produced at the laboratory. ${ }^{25}$

Serum for the analysis of transferrin was frozen at $-20^{\circ} \mathrm{C}$ and delivered to the Division of Medical Chemistry at the Swedish National Institute of Occupational Health where it was stored at $-70^{\circ} \mathrm{C}$ until analysis. The determination of total transferrin and the fraction of transferrin with an isoelectric point of $5.7\left(\mathrm{TF}_{5.7}\right)$ was performed according to Petrén and Vesterberg. ${ }^{26}$

Subjects with values above the 90th percentile of the distribution among the carpenters in any of ASAT, ALAT, ALP, BIL, GGT, or the bile acids were also defined as showing possible signs of liver dysfunction.

\section{STATISTICAL METHODS}

The data were analysed with multiple linear regression and logistic regression. Logistic regression was used when analysing data concerning possible signs of liver dysfunction. For the logistic regression analyses of separate tests the results were dichotomised at the 90th percentile of the distribution among the carpenters. Multiple linear regression was used for continuous outcome variables. All outcomes that were not normally distributed were positively skewed and were converted into logarithms for the multiple linear regression analyses.

Multiple linear regression analyses were performed with continuous or discrete exposure or potential confounder variables categorised as stated earlier. Dummy variables were created from exposure variables with more than two categories.

Cross tabulations were performed between all exposure and all potential confounder variables. In general there were weak associations between exposure variables and potential confounder variables and between different potential confounder variables. In instances where obvious associations existed-as for example between lifetime cumulative exposure estimates and age-there was still a reasonable representation in all cells of the cross tables and there was never reason to exclude any variable due to collinearity. The associations between different exposure variables were weak or moderate except for the association between LTSE and MEYSE where only one painter in the category with high LTSE belonged to the category with low MEYSE and only two painters with high MEYSE belonged to those with low LTSE.

In the analyses the effect of the different exposure estimates, one at a time, was investigated in the entire study group with no adjustment for potential confounders. Then the effects of the exposure estimates, one at a time, were investigated adjusting for all potential confounder variables relevant to the particular analysis. The computer packages SAS and EGRET were used for the analyses.

In all statistical analyses the regression coefficients for the exposure estimates were similar with and without adjustment for potential confounders. The results presented are adjusted for potential confounders.

\section{Results}

POSSIBLE SIGNS OF LIVER DYSFUNCTION

Possible signs of liver dysfunction were more common among painters than among carpenters (OR $1.5,95 \% \mathrm{CI}=0.8-2.8$ after adjustment for potential confounders). The proportion of subjects with this outcome seemed to increase with increasing MEYSE and LTSE (table 4) but not with increasing LYSE, LTWBE, or LYWBE. The doseresponse relations in table 4 were similar among those who had been exposed or not exposed to solvent and water based paints during the past year.

Among the painters analyses were performed with the MEYSE and LTSE exposure estimates entered together. In these analyses the ORs for MEYSE were unchanged whereas estimates for LTSE decreased. There was a tendency towards an interaction between intake of medicines and MEYSE or LTSE so that the increase in ORs with increasing exposure was more evident among those taking 
Table 4 ORs, with adjustment for potential confounders, of showing an abnormal value in at least one of the tests GGT, $A L A T, A L P, A S A T, C H E N O, C H O L, B I L$ among painters in different LTSE categories compared with carpenters ( $n=$ number affected, $N=$ number in group)

\begin{tabular}{|c|c|c|c|c|c|c|c|}
\hline \multirow[b]{2}{*}{$\begin{array}{l}\text { Exposure } \\
\text { estimate }\end{array}$} & \multicolumn{7}{|c|}{ Exposure category } \\
\hline & $\begin{array}{l}\text { Carpenters } \\
n / N \quad O R\end{array}$ & $\begin{array}{l}\text { Painter } \\
n / N\end{array}$ & OR $(95 \%$ CI $)$ & $\begin{array}{l}\text { Painter } \\
n / N\end{array}$ & $\begin{array}{l}s \text { intermediate } \\
O R(95 \% C I)\end{array}$ & $\begin{array}{l}\text { Painters } \\
n / N\end{array}$ & $\begin{array}{l}\text { high } \\
\text { OR }(95 \% \text { CI) }\end{array}$ \\
\hline $\begin{array}{l}\text { LTSE } \\
\text { MEYSE }\end{array}$ & $\begin{array}{ll}24 / 70 & 1 \cdot 0 \\
24 / 70 & 1 \cdot 0\end{array}$ & $\begin{array}{l}11 / 34 \\
10 / 32\end{array}$ & $\begin{array}{l}0.9(0.4-2.3) \\
1.0(0.4-2.4)\end{array}$ & $\begin{array}{l}28 / 65 \\
27 / 68\end{array}$ & $\begin{array}{l}1.6(0.8-3.3) \\
1.3(0.6-2.7)\end{array}$ & $\begin{array}{l}18 / 34 \\
20 / 33\end{array}$ & $\begin{array}{l}2 \cdot 4(1 \cdot 0-5 \cdot 7) \\
3 \cdot 1(1 \cdot 3-7 \cdot 4)\end{array}$ \\
\hline
\end{tabular}

medicines potentially harmful to the liver.

None of the potential confounders was significantly associated with the outcome.

ANALYSES OF SEPARATE TESTS OF LIVER FUNCTION AND URINARY ALBUMIN

There were only small differences in the median values of separate function tests between the carpenters' and the painters' groups formed on the basis of LTSE (table 5). In the multiple linear regression analyses the highest LTSE category showed higher ALP values than the carpenters $(p=0.02)$. The category with the highest MEYSE also showed significantly raised ALP activities $(p=0.05)$. These effects were, however, due in large extent to an interaction between the stated intake of medicines potentially harmful to the liver and these exposure estimates (table 6). Medicine significantly increased ALP activity among those with intermediate as well as heavy solvent exposures according to the MEYSE and LTSE exposure estimates. There was no difference in ALP activity between those with a high LTSE or MEYSE who had been exposed to solvents during the past year and the corresponding groups without solvent exposure.
No exposure estimate was significantly associated with any other outcome variable. The logistic regression analyses of the separate tests did not reveal any associations not apparent in the multiple linear regression analyses.

Of the potential confounders studied a high alcohol consumption and a high Broca's index were associated with significantly higher GGT, urinary albumin, and ALAT values than low alcohol consumption and low Broca's index. A high systolic blood pressure was significantly associated with higher urinary albumin values than low systolic blood pressure.

\section{Discussion}

The results suggest that heavy exposure to paint solvents has effects on the liver, but not on the kidney glomeruli. Our estimates of exposure to water based paints were not significantly associated with any outcome.

We firstly consider whether biases could explain these findings and which type of exposure caused the effects. Finally we discuss the findings in the light of previous investigations.

Table 5 Median values and ranges of tests of liver and kidney function among carpenters and among painters with low, intermediate, and high LTSE

\begin{tabular}{|c|c|c|c|c|c|c|c|c|}
\hline \multirow{4}{*}{$\begin{array}{l}\text { Test (unit and reference } \\
\text { interval or upper } \\
\text { reference limit in laboratory) } \\
\text { GGT }(<1.0 \mu \mathrm{kat} / \mathrm{l}) \\
\text { TF }_{5.7}(\%) \\
\text { Urinary albumin }(\mathrm{mg} / \mathrm{mmol} \\
\text { creatinine) }\end{array}$} & \multicolumn{8}{|c|}{ LTSE category } \\
\hline & \multirow{2}{*}{\multicolumn{2}{|c|}{$\begin{array}{l}\text { Carpenters } \\
(n=71) \\
\text { Median Range }\end{array}$}} & \multirow{2}{*}{\multicolumn{2}{|c|}{$\begin{array}{l}\text { Painters low } \\
(n=34) \\
\text { Median Range }\end{array}$}} & \multicolumn{2}{|c|}{$\begin{array}{l}\text { Painters intermediate } \\
(n=67)\end{array}$} & \multirow{2}{*}{\multicolumn{2}{|c|}{$\begin{array}{l}\text { Painters high } \\
(n=34) \\
\text { Median Range }\end{array}$}} \\
\hline & & & & & Medi & Range & & \\
\hline & $\begin{array}{l}0.6 \\
1.6 \\
0.9\end{array}$ & $\begin{array}{l}0 \cdot 1-8 \cdot 7 \\
0 \cdot 7-3 \cdot 2 \\
0 \cdot 3-57\end{array}$ & $\begin{array}{l}0.6 \\
1.8 \\
1.0\end{array}$ & $\begin{array}{l}0 \cdot 3-3 \cdot 0 \\
1 \cdot 0-2 \cdot 8 \\
0 \cdot 2-66\end{array}$ & $\begin{array}{l}0.6 \\
1.8 \\
0.9\end{array}$ & $\begin{array}{l}0 \cdot 3-4 \cdot 6 \\
0 \cdot 9-4 \cdot 4 \\
0 \cdot 2-25\end{array}$ & $\begin{array}{l}0.6 \\
1.7 \\
1.1\end{array}$ & $\begin{array}{l}0 \cdot 2-3 \cdot 7 \\
0 \cdot 9-2 \cdot 3 \\
0 \cdot 2-10 \cdot 4\end{array}$ \\
\hline $\begin{array}{l}\text { Urinary albumin }(\mu \mathrm{g} / \mathrm{min}) \\
\text { ALAT }(<0 \cdot 70 \mu \mathrm{kat} / 1) \\
\text { ALP }(<4 \cdot 6 \mu \mathrm{kat} / 1) \\
\text { ASAT }(<0 \cdot 70 \mu \mathrm{kat} / 1) \\
\text { CHENO }(<2 \cdot 4 \mu \mathrm{mol} / 1) \\
\text { CHOL }(<1 \cdot 1 \mu \mathrm{mol} / 1) \\
\text { BIL }(<22 \mu \mathrm{mol} / 1) \\
\text { Serum albumin }(37-52 \mathrm{~g} / 1)\end{array}$ & $\begin{array}{l}8 \cdot 0 \\
0 \cdot 43 \\
2 \cdot 8 \\
0 \cdot 48 \\
0 \cdot 6 \\
0 \cdot 5 \\
10 \\
45\end{array}$ & $\begin{array}{l}2 \cdot 6-458 \\
0 \cdot 12-3 \cdot 9 \\
1 \cdot 0-4 \cdot 9 \\
0 \cdot 22-2 \cdot 82 \\
0 \cdot 1-4 \cdot 0 \\
0 \cdot 1-2 \cdot 9 \\
2-24 \\
36-52\end{array}$ & $\begin{array}{l}8 \cdot 3 \\
0 \cdot 45 \\
2 \cdot 7 \\
0 \cdot 44 \\
0 \cdot 5 \\
0 \cdot 6 \\
9 \\
47\end{array}$ & $\begin{array}{l}2 \cdot 4-417 \\
0 \cdot 07-1 \cdot 73 \\
1 \cdot 1-4 \cdot 1 \\
0 \cdot 15-1 \cdot 53 \\
0 \cdot 1-2 \cdot 7 \\
0 \cdot 1-2 \cdot 1 \\
2-42 \\
41-54\end{array}$ & $\begin{array}{l}7 \cdot 6 \\
0 \cdot 51 \\
2 \cdot 7 \\
0 \cdot 46 \\
0 \cdot 4 \\
0 \cdot 5 \\
9 \\
46\end{array}$ & $\begin{array}{l}0-171 \\
0 \cdot 06-1 \cdot 81 \\
1 \cdot 9-4 \cdot 9 \\
0 \cdot 17-1 \cdot 68 \\
0 \cdot 1-2 \cdot 9 \\
0 \cdot 1-2 \cdot 5 \\
2-26 \\
39-52\end{array}$ & $\begin{array}{l}8 \cdot 5 \\
0 \cdot 46 \\
3 \cdot 1 \\
0 \cdot 43 \\
0 \cdot 5 \\
0 \cdot 6 \\
10 \\
45\end{array}$ & $\begin{array}{l}0-111 \\
0 \cdot 13-0 \cdot 32 \\
1 \cdot 9-6 \cdot 8^{\star} \\
0 \cdot 18-1 \cdot 03 \\
0 \cdot 1-2 \cdot 4 \\
0 \cdot 1-1 \cdot 9 \\
5-20 \\
38-50\end{array}$ \\
\hline
\end{tabular}

Statistical comparisons are based on $\log$ ALP values.

${ }^{\star} \mathrm{p}=0.02 v$ carpenters (with adjustment for potential confounders).

Table 6 Median and range of ALP values ( $\mu$ kat/l), in solvent exposure categories, among those stating (sm), and not stating (nsm), intake of medicines potentially harmful to the liver

\begin{tabular}{|c|c|c|c|c|c|c|c|c|c|c|c|c|}
\hline \multirow{3}{*}{$\begin{array}{l}\text { Exposure } \\
\text { estimate }\end{array}$} & \multicolumn{12}{|c|}{ Exposure category } \\
\hline & \multicolumn{3}{|c|}{ Carpenters } & \multicolumn{3}{|c|}{ Painters low } & \multicolumn{3}{|c|}{ Painters intermediate } & \multicolumn{3}{|c|}{ Painters high } \\
\hline & $N$ & Median & Range & $N$ & Median & Range & $N$ & Median & Range & $N$ & Median & Range \\
\hline \multicolumn{13}{|l|}{ LTSE } \\
\hline sm & 11 & 2.5 & $1 \cdot 0-4 \cdot 3$ & 5 & $3 \cdot 1$ & $1.8-3.9$ & $\begin{array}{l}10 \\
56\end{array}$ & $\begin{array}{l}3 \cdot 3 \\
2 \cdot 7\end{array}$ & $\begin{array}{l}2 \cdot 1-4 \cdot 9^{\star} \\
1.9-3 \cdot 8\end{array}$ & $\begin{array}{l}10 \\
24\end{array}$ & $\begin{array}{l}3.2 \\
3.0\end{array}$ & $\begin{array}{l}2 \cdot 1-6 \cdot 8^{\star} \\
1 \cdot 9-4 \cdot 0\end{array}$ \\
\hline \multicolumn{13}{|l|}{ MEYSE } \\
\hline $\begin{array}{l}\text { sm } \\
\text { nsm }\end{array}$ & $\begin{array}{l}11 \\
60\end{array}$ & $\begin{array}{l}2 \cdot 5 \\
2 \cdot 8\end{array}$ & $\begin{array}{r}1 \cdot 0-4 \cdot 3 \\
1 \cdot 4-4.9\end{array}$ & $\begin{array}{l}5 \\
27\end{array}$ & $\begin{array}{l}2 \cdot 5 \\
2 \cdot 8\end{array}$ & $\begin{array}{l}2 \cdot 1-3 \cdot 8 \\
1.9-4 \cdot 1\end{array}$ & $\begin{array}{l}14 \\
55\end{array}$ & $\begin{array}{l}3 \cdot 1 \\
2 \cdot 7\end{array}$ & $\begin{array}{l}1 \cdot 8-4.9 \dagger \\
1 \cdot 1-3 \cdot 8\end{array}$ & $\begin{array}{l}6 \\
27\end{array}$ & $\begin{array}{l}3.5 \\
2.9\end{array}$ & $\begin{array}{l}3 \cdot 2-6 \cdot 8 \ddagger \\
1 \cdot 3-4 \cdot 0\end{array}$ \\
\hline
\end{tabular}

Statistical comparisons are based on $\log$ ALP values

$\star_{p}=0.01 ;$ tp $=0.03 ; \neq \mathrm{p}=0.002$ compared with carpenters stating intake of medicines (with adjustment for potential confounders). 
POTENTIAL SOURCES OF BIAS

Sensitivity and specificity of tests

The most reliable way of measuring possible chronic changes in liver function is to employ some clearance test, such as galactose elimination or indocyananine green clearance. ${ }^{2728}$ Such methods are, however, time consuming, generally require hospital facilities, or involve some risk for complications. Thus they are not readily used for screening workers for subclinical effects.

Many of the tests used by us, such as ASAT, ALAT, GGT, and $\mathrm{TF}_{5.7}$, mostly reflect current hepatocellular injury ${ }^{27}$ and would be expected to be sensitive to effects from ongoing exposure. Some of these tests were in fact found to be quite sensitive to alcohol consumption as well as the degree of obesity.

The compounds measured in the routine liver function tests are usually also increased in liver cirrhosis and other chronic liver diseases. ${ }^{27}$ For example, an increase of at least one of ASAT, ALAT, GGT, ALP, BIL, or CHOL was found in all 51 cases of liver cirrhosis among outpatients with liver disease. ${ }^{29}$ Thus the combination of tests used in possible signs of liver dysfunction was the outcome most likely to reflect chronic effects on the liver. We made calculations to determine whether ALP or any other particular test had a large influence on possible signs of liver dysfunction but this was not found to be the case.

On the other hand the specificity of the possible sign of liver dysfunction outcome is rather weak. It has been shown that $30 \%$ of outpatients with various gastrointestinal disturbances showed abnormal levels in at least one of the tests used for the outcome in our study. ${ }^{29}$ Thus our findings seem to require further investigation concerning the tissue of origin of the increased occurrence of possible signs of liver dysfunction in heavily exposed workers in our study.

Urinary albumin has been shown to be increased among workers with ongoing solvent exposure in several investigations and also in early stages of diabetes nephropathy. ${ }^{30}$ Therefore it seems likely that clinically significant acute as well as chronic effects on kidney glomeruli induced by solvents should have been detected in our study, had they been present.

\section{Misclassification and confounding}

In this study information on exposure was obtained from the subjects themselves. Thus there is a possibility that unhealthy subjects with different symptoms and increased level of some liver function test may have exaggerated their exposure. We believe, however, that the careful exposure interview covering all activities involving solvent exposure for all years since the beginning of exposure will have greatly diminished this possibility.

In particular ALP activity increased with increasing solvent exposure among those who, currently or previously for a long period, took medicines with potential liver toxicity. This may have reflected the fact that subjects with heavy exposure had taken larger quantities of such medicines than those with low, or no, exposure. No difference was evident, however, between those with low and heavy exposure either concerning types of medicines used or the amount of medicine taken. Neither were the results changed if those currently taking medicines were calculated separately.

WHICH TYPE OF EXPOSURE MAY HAVE CAUSED THE EFFECTS ON LIVER FUNCTION TESTS?

Increasing solvent exposure according to the LTSE as well as MEYSE estimates were associated with increasing prevalence of possible signs of liver dysfunction and of increasing ALP activity among those taking medicine. Exposure to solvents during the past year seemed to lack importance for all outcomes. The LTSE and MEYSE exposure estimates were collinear and it is not possible to determine whether one of them were more influential than the other. Moreover they may both be related to some other exposure estimate that is really causing the effects. Heavy MEYSE exposure yielded the highest risk estimate for possible signs of liver dysfunction, however, and when LTSE and MEYSE were included in the same logistic regression model the risk estimates for LTSE tended to decrease. This suggests that not only cumulative solvent exposure but also particularly heavy exposures during shorter time periods need to be assessed in studies of liver effects from solvents.

COMPARISON WITH PREVIOUS INVESTIGATIONS The association and dose-response trend between two measures of solvent exposure and possible signs of liver dysfunction support the idea of a chronic effect from solvent exposure on the liver. We are not aware of previous investigations using this or similar outcomes to measure such effects.

The only separate test of liver dysfunction related to any exposure estimate was measurement of ALP activity. In a previous study it was suggested that this test is one of the most specific for mild chronic hepatic injury due to environmental agents. ${ }^{28}$ Workers with current exposure to mixed solvents and toluene have shown specific increases in this enzyme in serum $^{31}{ }^{32}$ but interactive effects between medicines taken and solvent exposure were not reported. Such an interaction has been suggested, however, by previous case reports. ${ }^{33}$

Our results concerning ALP suggest a mild, chronic solvent effect on the liver that is manifested among those who take medicines with potential effects on the liver.

Several studies have shown that exposure to mixed solvents does not affect common liver enzymes such as ALAT, ASAT, and GGT in serum ${ }^{2-46}$ and our results are compatible with these findings.

Recent studies of workers with ongoing exposure to mixed solvents have shown an increase in serum bile acids ${ }^{67}$ but another recent study $^{34}$ did not confirm this effect among workers with probably heavy current 
exposure to mixed solvents. Workers exposed to rather low concentrations of mixed solvents have shown an increase of $\mathrm{TF}_{5.7}{ }^{35}$. Furthermore some other studies have reported effects on $\mathrm{TF}_{5.7}$ in workers exposed to various organic chemicals. ${ }^{36} 37$

The painters examined by us had a previously heavy solvent exposure with no or low current exposure. Thus it is possible that these painters had previously had increased bile acids and $\mathrm{TF}_{5.7}$, which had returned to control group concentrations with decreasing exposure. It has been shown that serum bile acid concentrations normalise within a week after ceasing heavy alcohol intake. ${ }^{38} \quad \mathrm{TF}_{5.7}$ decreases noticeably in alcoholic patients within a few weeks of abstinence and after moderate misuse it remains at normal levels. ${ }^{26}$

No effect on urinary albumin from solvent exposure was seen although increases have been found in several studies of workers with a substantial current solvent exposure. ${ }^{13-16}$ It is possible that the workers studied by us have experienced reversible kidney effects.

It is concluded that heavy previous exposure to solvents from solvent based paints, with no or low current exposure, may elicit changes in routine liver function tests indicative of mild chronic effects on the liver. Furthermore our findings suggest that an interaction between exposure to solvents and medicines potentially harmful to the liver may be important in the causation of these effects.

Urinary albumin concentrations seemed not to be affected by solvent exposure.

Our estimates of exposure to water based paints seemed unrelated to all outcomes investigated.

The results merit further investigations to ascertain whether the liver is the true tissue of origin of the indications of chronic liver effects from solvent exposure obtained in this study. If so, it also needs to be clarified whether these effects have clinical significance.

We thank Annika Gustavsson who assisted in the data analysis, and Sven Petrén, Birgit Ákerlund, and Helene Saranius who performed the transferrin and urinary albumin analyses. who performed the transferrin and urinary albumin analyses. Bengt Sjögren gave critical comments on the manuscript. The study

1 Lundberg I, Hogstedt C, Lidén C, Nise G. Organic solvents. In: McCullen R, Rosenstock L, eds. Clinical occupational and environmental medicine. New York: Saunders Company, 1994 (in press).

2 Kurppa K, Husman K. Car painters exposure to a mixture of organic solvents. Serum activities of liver enzymes. Scand f Work Environ Health 1982;8:137-40.

3 Lundberg I, Hákansson M. Normal serum activities of liver enzymes in Swedish paint industry workers with heavy exposure to organic solvents. $\mathrm{Br} f$ Ind Med 1985 42:596-600.

4 Waldron HA, Cerry N, Venables H. Solvent exposure and liver function. Lancet 1982;ii: 1276 .

5 Edling C, Tagesson C. Raised serum bile acid concentrations after occupational exposure to styrene: a possible 列

6 Franco G, Fonte $R$, Tempini G, Candura F. Serum bile acid concentrations as a liver function test in workers occupationally exposed to organic solvents. Int Arch Occup Environ Health 1986;58:157-64

7 Franco G, Santagostino G, Lorena M, Imbriani M Conjugated serum bile acid concentrations in workers exposed to low doses of toluene and xylene. $\mathrm{Br} \mathcal{F}$ Ind Med 1989;46:141-2.

8 Franco G. New perspectives in biomonitoring liver function by means of serum bile acids: experimental and hypothetical biochemical basis. $\mathrm{Br} \mathcal{F}$ Ind Med 1991;48: 557-61.

9 Ravnskov U, Forsberg B, Skerfving S. Glomerulonephritis and exposure to organic solvents. A case-control study. Acta Med Scand 1979;205:575-9.

10 Bell G, Gordon A, Lee P, Doig A, MacDonald M Thomson D, et al. Proliferative glomerulonephritis and exposure to organic solvents. Nephron 1985;40:161-5.

11 van der Laan G. Chronic glomerulonephritis and organic solvents. Int Arch Occup Environ Health 1980;47:1-8.

12 Harrington J, Whitby $H$, Gray C, Reid F, Aw T, Waterhouse J. Renal disease and occupational exposure Med 1989;46:643-50.

13 Askergren A, Allgén L-G, Karlsson C, Lundberg I, Nyberg E. Studies on kidney function in subjects exposed to organic solvents. I. Excretion of albumin and beta-2 microglobulin in the urine. Acta Med Scand 1981;209: 479-83.

14 Lauwerys R, Bernard A, Viau C, Buchet J. Kidney disorders and hematotoxicity from organic solvent exposure. Scand $\mathcal{F}$ Work Environ Health 1985;11 (suppl 1):83-90.

15 Hotz P, Pilliod J, Berode M, Rey F, Boillat M. Glycosaminoglycans, albuminuria and hydrocarbon exposure. Nephron 1991;58:184-91.

16 Hotz P, Pilliod J, Söderström D, Rey F, Boillat M, Savolainen $H$. Relation between renal function tests and a retrospective organic solvent exposure score. $\mathrm{Br} F$ Ind Med 1989;46:815-9.

17 Franchini I, Cavatorta A, Falzoi M, Lucertini S, Mutti A Early indicators of renal damage in workers exposed to Early indicators of renal damage in workers exposed to organ

$18 \mathrm{Ng} \mathrm{T}$, Ong S, Lam $W$, Jones $M$, Cheung C, Ong C Urinary levels of proteins and metabolites in worker exposed to toluene. A cross-sectional study. Int Arch Occup Environ Health 1990;62:43-6.

19 Vyskocil A, Popler A, Skutilova I, et al. Urinary excretion of proteins and enzymes in workers exposed to hydrocarbons in a shoe factory. Int Arch Occup Environ Health 1991;63:359-62.

20 Bobjer O, Knave B. Work load and exposure to solvents and dust hazard factors in house painting. In: International symposium on the control of air pollution in International symposium on the control of air pollution in Environment Fund International Labour Office, 1977: Environ

21 Lundberg I, Gustavsson A, Högberg M, Nise G. Diagnoses of alcohol abuse and other neuropsychiatric disorders among house painters compared with house carpenters. Br f Ind Med 1992;49:409-15.

22 Riala R, Kalliokoski P, Pyy L, Wickström G. Solvent exposure in construction and maintenance painting. Scand $\mathcal{f}$ Work Environ Health 1984;10:263-6.

23 Fidler AT, Baker EL, Letz R. Estimation of long term exposure to mixed solvents from questionnaire data: tool for epidemiological investigations. $\mathrm{Br} \mathrm{F}$ Ind $\mathrm{Med}$ 1987;44:133-41.

24 Vesterberg $O$. Quantification of albumin in urine by a new method: zone immuno-electrophoresis assay (ZIA). Clin Chim Acta 1981;113:305-10.

25 Samuelsson K, Johansson C, Norman A. Serum bile acids after a test meal in Crohn's disease. Scand 7 Clin Invest 1979;39:511-8.

26 Petrén S, Vesterberg $O$. Concentration differences in isoforms of transferrin in blood from alcoholics during abuse and abstinence. Clin Chim Acta 1988;175:183-8.

27 Price C, Alberti K. Biochemical assessment of liver function. In: Wright $R$, Alberti K, Karran S, Millward-Sadle $\mathrm{G}$, eds. Liver and biliary diseases. London: WB Saunders, 1979:381-416.

28 Tamburro C, Greenberg R. Effectiveness of federally required medical laboratory screening in the detection of
chemical injury. Environ Health Perspect 1981;41:117-22.

29 Samuelsson K, Aly A, Johansson C, Norman A. Evaluation of fasting serum bile acid concentration in patients with liver and gastrointestinal disorders. Scand 7 Gastroent 1981;16:225-34.

30 Mogensen CE. Microalbuminuria as a predictor of clinical diabetic nephropathy. Kidney Int 1987;31:673-89.

31 Elofsson SA, Gamberale F, Hindmarsh T, et al. Exposure to organic solvents. A cross-sectional epidemiological investigation on occupationally exposed car and industrial spray painters with special reference to the nervous system. Scand $\mathcal{f}$ Work Environ Health 1980;6:239-73.

32 Svensson BG, Nise G, Erfurth EM, Olsson H. Neuroendocrine effects in printing workers exposed to toluene. Brf Ind Med 1992;49:402-8.

33 Edling $C$. Interaction between drugs and solvents as a cause of fatty change in the liver. $\mathrm{Br} F$ Ind Med 1982; 39:198-9.

34 Hotz P, Pilliod J, Bourgeois R, Boillat M-A. Hydrocarbon exposure, pancreatitis, and bile acids. $\mathrm{Br} F$ Ind $\mathrm{Med}$ 1990;47:833-7.

35 Petrén $S$, Vesterberg $O$. Studies of transferrin in serum of workers exposed to organic solvents. $\mathrm{Br} \mathcal{F}$ Ind Med 1987;44:566-8.

36 Beving $H$, Malmgren $R$, Petrén $S$, Vesterberg $O$. Hematological changes in house painters using epoxy Hematological changes in house paint
paints. F Soc Occup Med 1991;41:102-6.

37 paints. F Soc Occup Med 19erg O. Increased isotransferrin ratio and reduced erythrocyte and platelet volumes in ratio and reduced erythrocyte and platelet volumes in Hyg 1990;34:391-7.

38 Ahlgren A, Hedenborg G, Norman A, Wisén O. Serum bilirubin subfractions in patients with alcohol abuse during detoxication. Scand $\mathcal{F}$ Clin Lab Invest 1988;48: 319-26. 